\title{
New age constraints for the Ordovician Tyrone Volcanic Group, Northern Ireland
}

\author{
M. R. COOPER ${ }^{1}$, Q. G. CROWLEY ${ }^{2}$ \& A. W. A. RUSHTON ${ }^{3}$ \\ ${ }^{1}$ Geological Survey of Northern Ireland, Colby House, Stranmillis Court, Malone \\ Lower, Belfast BT9 5BJ (e-mail: mark.cooper@detini.gov.uk) \\ ${ }^{2}$ NERC Isotope Geoscience Laboratory, British Geological Survey, Kingsley Dunham \\ Centre, Keyworth, Nottingham NG12 $5 G G$ \\ ${ }^{3}$ Palaeontological Department, The Natural History Museum, Cromwell Road,
} London SW7 5BD.

\begin{abstract}
New biostratigraphical evidence and a high precision ID-TIMS U-Pb zircon age provide refined age constraint for the Ordovician Tyrone Volcanic Group of the Tyrone Igneous Complex. In a graptolite fauna from Slieve Gallion, the presence of Isograptus victoriae lunatus, the index fossil of the victoriae lunatus graptolite zone, indicates a correlation with the Australasian Castlemainian (Ca1) Stage. The U-Pb zircon age of $473 \pm 0.8 \mathrm{Ma}$ dates a volcanic arc-related rhyolite body that sits stratigraphically below graptolitic mudstones of Slieve Gallion. The U$\mathrm{Pb}$ isotopic and biostratigraphical age constraints match closely with an interpolated age for the base of the Middle Ordovician (Sadler \& Cooper 2004), and indicate a Whitlandian age for the upper Tyrone Volcanic Group, which supports the regional correlation with the Ballantrae Complex, Midland Valley Terrane, Scotland.
\end{abstract}

The Tyrone Igneous Complex extends over an area of approximately $350 \mathrm{~km}^{2}$ of Counties Tyrone and Londonderry in Northern Ireland. It is recognised as part of the basement of the Midland Valley Terrane of Scotland, Northern Ireland and Ireland (Fig. 1a) (Bluck et al. 1992). A strong regional link has been made between the Tyrone Igneous Complex and the Ballantrae Complex of Girvan (Bluck 1985), which together compose the Tyrone-Girvan sub-terrane. In a broader context, the Tyrone Igneous Complex appears to fit most closely with the Notre Dame Subzone of the Dunnage Zone of Newfoundland, as described in Van Staal et al. (1998). 
Although the distinctive array of igneous and sedimentary lithologies present in the Tyrone Igneous Complex was recognised by the Geological Survey of Ireland in the $19^{\text {th }}$ Century, it was Hartley (1933) who first appreciated the lithological and stratigraphical similarities between it and the Arenig Ballantrae Igneous Group in the Girvan area of southwest Scotland. This correlation was apparently dispelled when Hartley (1936) reported very rare graptolites from "black shales" in the upper part of the Tyrone Igneous Complex on Slieve Gallion, which appeared to indicate a Llandeilo-early Caradoc age. Remapping of the Pomeroy area by the Geological Survey of Northern Ireland (1979), led to the recognition of the two groups of rocks that now constitute the Tyrone Igneous Complex, namely the structurally lower Tyrone Plutonic Group overlain by the Tyrone Volcanic Group (Fig. 1b). The resurvey also identified the varied lithologies and temporal array of the major intrusive bodies that are present. However, no new evidence for the age of the Tyrone Igneous Complex was forthcoming and indeed the possibility of a Dalradian age for the basal Plutonic Group was suggested (Geological Survey of Northern Ireland 1979).

The geological significance of the Tyrone Igneous Complex again changed with the seminal work of Hutton et al. (1985), who recognised the ophiolitic affinity of the Tyrone Plutonic Group, and demonstrated a basic igneous association of layered, isotropic and pegmatitic gabbros, doleritic sheeted dykes and rare basaltic pillow lavas. In the overlying Tyrone Volcanic Group they identified the components of a volcanic arc sequence, comprising pillow lavas, tuffs of basic to intermediate composition, rhyolites, chert, siltstone and dark grey mudstone representing up to three volcanic cycles. Further graptolite specimens discovered by Hutton \& Holland (1992) at the locality on Slieve Gallion pointed to a much older age for the Tyrone Volcanic Group within the Ordovician than proposed by Hartley (1936), but were still somewhat indefinite, being long-ranging forms of Arenig-Llanvirn age.

Though individually fault-bound, the Tyrone Plutonic Group and Tyrone Volcanic Group are considered to be contemporaneous (Hutton \& Holland 1992; Parnell et al. 2000), and are pinned together by a suite of volcanic arc-related intrusions of Arenig to Llanvirn age (Noble et al. pers. comm.). A tonalite intrusion belonging to this suite, located at Craigballyharky northeast of Pomeroy (Fig. 1b), with a published U$\mathrm{Pb}$ zircon age of $471^{+2} /_{4}$ (Hutton et al. 1985), intrudes and mixes with gabbro (Angus 1962, 1977) thought to belong to the Tyrone Plutonic Group ophiolite. Such magma 
mixing demonstrates that the gabbro was still molten at the time of tonalite intrusion, and hence an Arenig age for part of the Tyrone Plutonic Group is conceivable. This paper provides a more refined biostratigraphical age for mudstones within the Tyrone Volcanic Group, and presents a high precision $\mathrm{U}-\mathrm{Pb}$ isotopic age for an underlying volcanic arc-related rhyolite body.

\section{Biostratigraphy}

\section{Previous biostratigraphy}

Biostratigraphical evidence for the Ordovician age of the Tyrone Volcanic Group of the Tyrone Igneous Complex has been based solely on small collections of fragmentary graptolites from one locality in the Sruhanleanantawey stream at IGR 2790538790 (Fig. 1b). The stream section, on the northwest slopes of Slieve Gallion [from IGR 27883886 to IGR 2790138785 ], exposes a variety of lithologies including greenish grey tuffs and lava with hornblende and feldspar phenocrysts, chert, light grey, thin bedded tuffaceous siltstone and dark grey, thin to medium bedded mudstone with variable amounts of tuffaceous debris and pyrite.

The graptolite specimens discovered by Hartley (1936) were identified as Dicranograptus (most probably Dicranograptus rectus), and Climacograptus which indicated an upper Llandeilo to lower Caradoc age and a correlation with volcanic rocks at the base of the succession in North Co. Down in the Southern UplandsDown-Longford Terrane (Fig.1a; Anderson et al. 2004). Further graptolite specimens collected by Hutton in the 1980's were identified (Hutton \& Holland 1992) as Tetragraptus serra (Brongniart) and Sigmagraptus s.l. The age defined by these graptolites is somewhat indefinite since the former is recorded throughout the Arenig and possibly the early Llanvirn (VandenBerg \& Cooper 1992), whilst the Sigmagraptus, though likely of Arenig age, are too fragmentary to be identified with certainty. However, the evidence provided by Hutton and Holland clearly demonstrated that the Tyrone Volcanic Group was much older than previously envisaged by Hartley and was broadly attributable to the Arenig-Llanvirn.

\section{New biostratigraphy}

In order to improve biostratigraphical control for the Tyrone Volcanic Group, a search for additional fossil evidence was undertaken. Although no new fossiliferous 
localities were found, the historical locality on Slieve Gallion was recollected and more than twenty graptolites and a brachiopod were recovered that now form the basis of this study. Most of the new graptolite specimens collected are fragmentary and slightly deformed (the eccentricity of the strain-ellipse in the plane of bedding is estimated to be about 1.2:1), but it has been possible to identify the forms listed below:

Large dichograptid stipe fragments (=Dichograptus?), Text-fig. 2b

Branched dichograptid fragment [indet.], Text-fig. 2c

Didymograptellus nitidus (J. Hall), Text-figs 2d-f, g?, k?

Isograptus victoriae lunatus Harris, Text-figs $2 \mathrm{~h}, \mathrm{i}, \mathrm{j}$

Lingulate brachiopod [umbo lies just forward of the posterior margin]

In addition, the specimens collected by Hutton \& Holland (1992) were re-examined. The thin stipes formerly identified as Sigmagraptus are presumably referable to the Sigmagraptidae, but could not be identified more closely. Further preparation of the specimen identified by Hutton and Holland as Tetragraptus serra revealed five stipes and it is now considered to be a pentad example of Dichograptus octobrachiatus (Text-fig. 2a).

Based on the identification of graptolites in the new collection, the fossiliferous mudstones of Slieve Gallion can be assigned to the Isograptus victoriae lunatus Zone of the Australasian graptolite succession (VandenBerg \& Cooper 1992) and to the lowest Ca1 subdivision of the Castlemainian Stage (Table 1); the base of this division lies very close to the triangulatus conodont zone, which is now taken internationally to represent the base of the Middle Ordovician (Cooper 1999). In terms of the British succession this horizon is approximately equivalent to a level at the top of the Whitlandian Stage of the Arenig.

The Castlemainian (Ca1) graptolites from Slieve Gallion are younger than other faunas so far recorded in the Ballantrae Complex (Ingham 2000), with the exception of the latest Castlemainian (Ca4) assemblage from the North Ballaird Borehole (Stone \& Rushton 2003; Maletz, Stone \& Rushton 2004). The latter fauna is rich in isograptid graptolites and is typical of deep-water assemblages in the low latitude 'Pacific Province' (Cooper et al. 1991). The fauna from Slieve Gallion is much less rich, but the presence of isograptids and sigmagraptine fragments reflects the Pacific 
Province rather than the 'Atlantic Province', though only weakly because isograptids do occasionally reach deep-water sites in the Atlantic Province (e.g. in the Skiddaw Group of the English Lake District and in North Wales), whilst Didymograptellus nitidus and Dichograptus octobrachiatus are regarded as pandemic and not restricted to a particular province (Cooper et al. 1991).

\section{Assessment of the graptolite fauna}

Stratigraphically the most significant find is Isograptus victoriae lunatus Harris (Figs. 2h?, i?, j). A juvenile proximal end from a cherty layer is flattened but is relatively undeformed (Fig. 2j). A fragmentary stipe on the same block that shows proximal curvature (Figs. 2h, i) is referred to the same species, but with some reserve. The sicula is $2.9 \mathrm{~mm}$ long, of which the supradorsal part is $0.6 \mathrm{~mm}$ wide and $1.4 \mathrm{~mm}$ long; sicular aperture $0.55 \mathrm{~mm}$ wide; ventral notch wide, $0.6 \mathrm{~mm}$ deep; nema preserved for nearly $1 \mathrm{~mm}$. Stipe width at th2 is 1.4 to $1.5 \mathrm{~mm}$, and this width is maintained on the longer stipe fragment which has a 2-theca repeat distance of 1.4 $\mathrm{mm}$ (equivalent to about 7 thecae in $5 \mathrm{~mm}$ ). There are 2 pairs of pendent thecae. These specimens therefore agree with I. victoriae lunatus (Cooper 1973, p. 59, textfig. 8), and most of the dimensions lie close to the mean for the subspecies (Cooper 1973, table, p. 112). The small number of pendent thecae is not matched by other $I$. victoriae subspecies.

In Australasia I. victoriae lunatus is confined to Ca1 of the Castlemainian, (VandenBerg \& Cooper 1992, p. 62), and it is used as a zonal fossil for the correlative level in western Newfoundland (Williams \& Stevens 1988). This lies within the much longer reported ranges of the other species now recorded from the Slieve Gallion site. The top of the victoriae lunatus graptolite zone, the lowest of four zones of the Castlemainian (VandenBerg \& Cooper 1992, p. 42), is correlated approximately with the top of the Whitlandian Stage of the British succession, and the base of the zone is used to recognise the base of the Middle Ordovician in graptolitebearing successions.

Dichograptus octobrachiatus (J. Hall), Figs 2a, b? Preparation of the specimen in the collections of Trinity College, Dublin, no. TCD.28759a-d (counterparts) shows that it has five stipes and it is now identified as a pentad form of Dichograptus octobrachiatus. This species most commonly has eight stipes, but Elles \& Wood 
(1902, p. 78, pl.10b, d, e) recorded specimens with 7, 6 or 5 stipes. The specimen in Fig 2 a agrees best with $D$. octobrachiatus, examples of which were described by Williams \& Stevens (1988); their text-fig. 14B shows a specimen with comparably close initial branching. Other robust species such as D. octonarius (Hall, 1865, pl. 10, figs 1,2) and D. solidus Harris \& Thomas (Cooper \& Fortey 1982, fig. 13) have the thecae more widely spaced. The stratigraphical range of D. octobrachiatus is long: VandenBerg \& Cooper (1992, p. 59) record its range in Australasia from the base of the Bendigonian to the middle of the Darriwilian (basal Arenig to mid-Llanvirn).

Didymograptellus nitidus (J. Hall), Figs 2d-f, g?, k?. Maletz (1994) transferred this species from the genus Expansograptus or subgenus Didymograptus (Expansograptus), where it was formerly placed, to his revised concept of Didymograptellus Cooper \& Fortey (1982, p. 220). In the new collection are two slender horizontal specimens of Didymograptellus (Figs 2d, 2e) that can be referred to D. nitidus, and a more doubtful robust specimen (Fig. 2k) that is poorly preserved proximally. The stratigraphical ranges recorded for D. nitidus in different regions are not consistent, possibly reflecting uncertainties surrounding the identification of some of the recorded material. According to Williams \& Stevens (1988, text-fig. 3) D. nitidus ranges through the Bendigonian and Chewtonian, not reaching the lunatus Zone at the base of the Castlemainian. VandenBerg \& Cooper (1992, p.60) give its range through the Chewtonian and into the lower half of the Castlemainian. In contrast, the British material referred to nitidus by Elles \& Wood (1901) occurs in strata of equivalent age to the mid- to late Castlemainian (Ca2-3) and early Yapeenian (Ya1). D. nitidus appears, therefore, to indicate only an undifferentiated Arenig age.

\section{U-Pb Dating}

\section{Sample location and selection}

The sample of very fine grained, flow-banded rhyolite analysed (MRC 290) was taken from a northeast-southwest orientated, elongate $(15 \mathrm{~km}$ by $0.5 \mathrm{~km})$, sheet-like body that stretches from the Fernagh Townland, $8 \mathrm{~km}$ southeast of Sixmilecross, through Cashel Rock to near Formil Hill 3 km east of Greencastle (Fig. 1b). This rhyolite body and other similar bodies are enclosed within a sequence composed predominately of basic to intermediate pillow lavas and tuffs. However, exposure in the study area is limited so there is uncertainty as to whether or not they are intrusive, extrusive or both. At Cashel Rock (Fig. 1b), rhyolite has a clearly intrusive contact with tonalite, 
whereas at Beaghbeg, another rhyolite body demonstrates brecciation and mixing at its margin with the background tuffs. Given these relationships and textural characteristics, the interpretation is that the rhyolite bodies were high-level and syndepositional so that both intrusive and extrusive contacts would be expected.

In terms of composition, and despite its grain size, the rhyolite was an obvious target for zircon $\mathrm{U}-\mathrm{Pb}$ isotopic dating. The body also sits structurally and stratigraphically lower than graphitic pelite and black chert bearing localities at Mountfield quarry and Broughderg that are thought to represent the top of the third volcanic cycle, and equate with the Slieve Gallion site where biostratigraphical constraint has been established. The sample site was located at Formil Hill [IGR 2617 3819] in a wellexposed area close to the middle of the body.

\section{Analytical Techniques}

Zircon fractions were analysed by Isotope Dilution Thermal Ionization Mass Spectrometry (ID-TIMS) at the NERC Isotope Geosciences Laboratory (NIGL). Analytical procedures are described in Noble et al. (1993). Zircon crystals were separated from $<355 \mu \mathrm{m}$ whole rock fraction using standard vibrating-table, specific gravity and magnetic techniques. Crystal fractions for analysis were picked by hand under a binocular microscope. A bulk zircon fraction was annealed at $800^{\circ} \mathrm{C}$ in quartz glass beakers for 48 hours. The zircon crystals were ultrasonically washed in $4 \mathrm{~N}$ $\mathrm{HNO}_{3}$, rinsed in ultra-pure water, then further washed in warm $4 \mathrm{~N} \mathrm{HNO}_{3}$ prior to rinsing with distilled water to remove surface contamination. The annealed, cleaned bulk zircon fraction was then chemically abraded in $200 \mu 129 \mathrm{~N} \mathrm{HF}$ and $20 \mu 18 \mathrm{~N}$ $\mathrm{HNO}_{3}$ at $120^{\circ} \mathrm{C}$ for 12 hours following a modified chemical abrasion technique to remove portions of grains which have suffered Pb-loss (Mattinson 2005). Chemically abraded zircons were washed several times in ultra-pure water, in warm $3 \mathrm{~N} \mathrm{HCl}$ for several hours on a hot-plate, rinsed again in ultra-pure water and $8 \mathrm{~N} \mathrm{HNO}_{3}$ and split into single grain fractions ready for dissolution. A mixed ${ }^{205} \mathrm{~Pb}-{ }^{235} \mathrm{U}$ tracer was used to spike all fractions. Dissolved, spike-equilibrated samples were not subjected to ionexchange procedures but were converted to chloride and loaded onto degassed rhenium filaments in silica gel following a procedure modified after Mundil et al. (2004). Isotope data were collected using a Thermo Electron Triton equipped with a new generation of MassCom Secondary Electron Multiplier (Noble et al. 2006). A minimum of 100 ratios were collected for $\mathrm{Pb}$ and 60 for $\mathrm{U} . \mathrm{Pb}$ ratios were scrutinised 
for any evidence of organic interferences which were determined to be negligible. Errors were calculated using numerical error propagation (Ludwig 1998). Isotope ratios were plotted using Isoplot version 3 (Ludwig 1999), and error ellipses reflect $2 \sigma$ uncertainty. Total procedural blanks were $0.2 \mathrm{pg}$ for $\mathrm{Pb}$ and $0.05 \mathrm{pg}$ for U. Samples were blank corrected for $0.2 \mathrm{pg}$ of $\mathrm{Pb}$, any residual common $\mathrm{Pb}$ was corrected using a Stacey-Kramers common lead composition (Stacey \& Kramers 1975).

\section{Results}

Four single grain zircon fractions were analysed (Table 2). Total amounts of radiogenic $\mathrm{Pb}$ were in the 50 to $200 \mathrm{pg}$ range. Of the four fractions analysed, one lies with the ellipse centroid below concordia but overlapping with the Concordia curve at 2 Sigma limits. Evidently, the effects of $\mathrm{Pb}$ loss were not totally removed by chemically abrasion at $120^{\circ} \mathrm{C}$. Higher temperature chemical abrasion may have compensated for this, but it would also result in less $\mathrm{Pb}$ being available for the final analysis. Given the relatively small single grain fractions prepared for analysis, it was decided to use a lower temperature for the chemical abrasion procedure. The remaining three single zircon fractions gave concordant analyses which overlap within error to give a concordia age of $473 \pm 0.8 \mathrm{Ma}$.

\section{Discussion}

The presence of Isograptus victoriae lunatus in the graptolite fauna from the Tyrone Volcanic Group provides the biostratigraphical evidence for correlation with the basal division of the Australasian Castlemainian (Ca1) Stage of the Arenig.

Sadler \& Cooper (2004, p. 49) tabulated several control points for the correlation of reliable isotopic ages with Ordovician stratigraphical constraints; they provided a regression line (Sadler \& Cooper 2004, fig. 3.1) from which model ages of the divisions of the Ordovician may be inferred. Although their regression line is well constrained in the Llanvirn and Caradoc series, age-dating of the earlier Ordovician is based largely on two good data points. One is an age of $469^{+5} /{ }_{-3}$ Ma (Tucker \& McKerrow 1995) for the Undulograptus austrodentatus Zone in the lower Darriwilian, equivalent to an horizon in the late Arenig; the other is a basal Tremadoc age of $489 \pm 0.6 \mathrm{Ma}$ (Landing et al. 2000). 
On Sadler \& Cooper's regression line the age of the base of the Middle Ordovician, though not supported by data-points, is interpolated at approximately $472 \mathrm{Ma}$. The rhyolite body in the Tyrone Volcanic Group, which underlies tectonised mudstones that are correlated with the early Castlemainian graptolitic strata, gave an isotopic age of $473.0 \pm 0.8 \mathrm{Ma}$. Our results therefore afford a data-point for placing the base of the Middle Ordovician a little later than $473 \mathrm{Ma}$, very close to what is suggested by Sadler \& Cooper's line. In terms of the British Ordovician, this points towards a Whitlandian age for much of the Tyrone Volcanic Group. In Girvan, the age control from graptolites of the Balcreuchan Group of the Ballantrae Complex (Stone \& Rushton 1983) shows it to have been deposited mainly during the Bendigonian and Chewtonian stages (see Table 1), correlated by Ingham (2000) approximately with the Moridunian and Whitlandian Stages of the basal to middle Arenig. When other similarities are taken into account, including the presence of lavas, agglomerates, tuffs, and cherts, the correlation between the Balcreuchan Group and Tyrone Volcanic Group is strong.

Also worthy of note is that the ophiolitic rocks of the Ballantrae Complex are predominantly from deeper within the ophiolite sequence than those seen in the Tyrone Plutonic Group. It is possible therefore, that we are seeing parts of the same ophiolite that have been obducted at different structural levels. The recent reassessment of the age and proposal of an obducted ophiolite model for Highland Border Complex of Scotland (Tanner \& Sutherland 2007), which shares a similar position as the Tyrone Igneous Complex at the northern margin of the Midland Valley Terrane, supports such a hypothesis.

\section{Conclusions}

The refined biostratigraphical age presented herein correlates the top of the Tyrone Volcanic Group at Slieve Gallion with the lower Castlemainian Stage (Ca1) of the Arenig.

The model age inferred by Sadler \& Cooper (2004) for the Ca1 horizon at the base of the Middle Ordovician, concurs with a high precision U-Pb zircon age of $473 \pm 0.8$ Ma that has been produced for a volcanic arc-related rhyolite from the Ordovician Tyrone Volcanic Group of the Tyrone Igneous Complex. 
When compared with the regression line of Sadler \& Cooper, the $473 \pm 0.8 \mathrm{Ma}$ zircon age for the Tyrone Volcanic Group rhyolite body sits just below the base of the Middle Ordovician within the Chewtonian Stage. This is consistent with the correlation of the overlying graptolitic mudstones of Slieve Gallion to the Australasian Castlemainian (Ca1).

The isotopic and biostratigraphical age constraint now available point towards a Chewtonian-early Castlemainian (= Whitlandian) age for much of the Tyrone Volcanic Group, and supports the regional correlation with the Ballantrae Complex of Girvan.

\section{Acknowledgements}

John Cobbing is thanked for sharing his regional knowledge of the Tyrone Igneous Complex. We thank Ian Mitchell (Geological Survey of Northern Ireland) for his assistance during specimen collection and for reviewing the manuscript. Phil Stone (BGS), Steve Noble (NIGL), Chris Kirkland, Richard Fortey, Garth Earls, Terry Johnston and Hugh Crilly are also gratefully acknowledged for constructive reviews and assistance during manuscript preparation. MRC and QGC publish with permission of the Executive Director of the British Geological Survey (NERC). Adrian Wood, Neil Boulton and Aaran Sumner are thanked for technical assistance at NIGL. This is NIGL publication 722. 


\section{References}

Anderson, T. B., Johnston, T. P. \& Mitchell, W. I. 2004. Basement Structure and the Terrane Model. In The Geology of Northern Ireland - Our Natural Foundation. Mitchell, W. I. (ed.). (Second Edition), Geological Survey of Northern Ireland, Belfast, 1-8.

ANGUS, N. S. 1962. Ocellar hybrids from the Tyrone Igneous Series, Ireland. Geological Magazine, 99, 9-26.

ANGuS, N. S. 1977. The Craigballyharkey Granitic Complex within the Tyrone Igneous Series. Proceedings of the Royal Irish Academy 77, B, 181-199.

BLUCK, B. J. 1985. The Scottish paratectonic Caledonides. Scottish Journal of Geology, 21, 437-464.

Bluck, B. J., GibBons, W. \& Ingham, J. K. 1992. Terranes. In Cope, J. C. W., Ingham, J. K and Rawson, P. F. (eds) Atlas of Palaeogeography and Lithofacies, Geological Society of London, Memoirs, 13, 1-4.

COOPER, R. A. 1973. Taxonomy and evolution of Isograptus Moberg in Australasia. Palaeontology, 16, 45-115.

COOPER, R. A. 1999. The Ordovician time scale - calibration of graptolite and conodont zones. Acta Universitatis Carolinae - Geologica 43 (1/2), 1-4.

COOPER, R. A. \& FORTEY, R. A. 1982. The Ordovician graptolites of Spitsbergen. Bulletin of the British Museum (Natural History), Geology 36, 157-302.

COOPER, R. A., ForTEY, R. A. \& LiNDHOLM 1991. Latitudinal and depth zonation of early Ordovician graptolites. Lethaia, 24, 199-218.

ELLES, G. L. \& WoOD, E.M.R. 1901-1902. Monograph of British Graptolites, Part 1 (1901), 1-54, pls 1-4, and Part 2 (1902), i-xxvii, 55-102, pls 5-13. Monographs of the Palaeontographical Society, London, parts of volumes for 1901, 1902.

Fortey, R. A. \& Owens, R. M. 1987. The Arenig Series in South Wales. Bulletin of the British Museum (Natural History), Geology, 41, 69-307.

Geological Survey of Northern Ireland 1979. Pomeroy, Northern Ireland Sheet 34. Solid Geology. 1:50,000. (Keyworth, Nottingham: British Geological Survey).

HALL, J. 1865. Figures and descriptions of Canadian Organic Remains. Decade II. Graptolites of the Quebec Group. Geological Survey of Canada. 151 pp., 23 pls. Montreal.

HARTLEY, J. J. 1933. The geology of North-Eastern Tyrone and adjacent portions of Co. Londonderry. Proceedings of the Royal Irish Academy, B41, 218-85. 
HARTLEY, J. J. 1936. The age of the Igneous Series of Slieve Gallion, Northern Ireland. Geological Magazine, 73, 226-28.

Hutton, D.H.W., Aftalion, M. \& Halliday, A. N. 1985. An Ordovician ophiolite in

County Tyrone, Ireland. Nature, 315, 210-12.

Hutton, D. H. W. \& Holland, C. H. 1992. An Arenig-Llanvirn age for the black shales of Slieve Gallion, County Tyrone. Irish Journal of Earth Sciences, 11, 187-189.

INGHAM, J. K. 2000. Scotland: the Midland Valley Terrane - Girvan. In FORTEY, R. A., Harper, D. A. T., Ingham, J. K., Owen, A. W., Rushton, A. W. A., \& WoodCock, N. P. 2000. A revised correlation of Ordovician rocks in the British Isles. Special Report of the Geological Society of London, no. 24, 83 pp. LANDing, E., Bowring, S. A., Fortey, R. A. \& DAVIDEK, K. L. 1997. U-Pb zircon date from Avalonian Cape Breton Island and geochronologic calibration of the Early Ordovician. Canadian Journal of Earth Sciences, 34, 724-30.

Landing, E., Bowring, S. A., Davidek, K. L. Rushton, A. W. A., Fortey, R. A., AND WimBledon, W. A. P. 2000. Cambrian-Ordovician boundary age and duration of the lowest Ordovician Tremadoc Series based on U-Pb zircon dates from Avalonian Wales. Geological Magazine, 137, 485-494.

LUDWIG, K.R. 1998. On the treatment of concordant uranium-lead ages. Geochimica et Cosmochimica Acta, 62(4), 665-676.

LUDWIG, K.R. 1999. Using Isoplot/Ex, Version 2.01: a geochronological toolkit for Microsoft Excel. Berkeley Geochronology Center Special Publication, 1a: 47.

MATTINSON, J. M. 2005. Zircon U-Pb chemical abrasion ("CA-TIMS") method: Combined annealing and multi-step partial dissolution analysis for improved precision and accuracy of zircon ages. Chemical Geology, 220. 47-66.

MALETZ, J. 1994. Pendent didymograptids (Graptoloidea, Dichograptacea). In Chen Xu, Erdtmann, B.-D., and Ni Yu-nan (eds), Graptolite Research Today, 27-43.

Maletz, J., Stone, P. \& Rushton, A. W. A. 2004. Late Castlemainian (Ca4, Arenig) graptolites from the Ballantrae Complex, SW Scotland; and Reply. Scottish Journal of Geology, 40, 185-187.

Mundil, R., Ludwig, K. R., MetCAlfe, I. \& RenNe, P. R. 2004. Age and timing of the Permian mass extinctions: $\mathrm{U} / \mathrm{Pb}$ dating of closed-system zircons. Science, $\mathbf{3 0 5}, 1760$ 1763.

Noble, S. R., Tucker, R. D. \& Pharoah, T. C. 1993. Lower Paleozoic and Precambrian igneous rocks from eastern England and their bearing on late Ordovician closure of the 
Tornquist sea: constraints from U-Pb and Nd isotopes. Geological Magazine, 130, 835846.

Noble, S., Schweiters, J., Condon, D. J., Crowley, Q. G., QuaAs, N. \& Parrish, R. 2006. TIMS characterization of new generation of secondary electron multiplier. Eos Trans. AGU, 87(52), Fall Meeting Supplement, http://www.agu.org/meetings/fm06/?content=program\&show=cd.

Parnell, J., Earls, G., Wilkinson, J. J., Hutton, D. H. W., Boyce, A. J., Fallick, A. E., Ellam, R. M., Gleeson, S. A., Moles, N. R., CAREy, P. F. \& LEgG, I. 2000. Regional Fluid Flow and Gold Mineralization in the Dalradian of the Sperrin Mountains, Northern Ireland. Economic Geology, 95, 1389-1416.

SAdLeR, P. M. \& COOPER, R. A. 2004. Calibration of the Ordovician Timescale. In B. D.

Webby, F. Paris, M. L. Droser, and I. G. Percival (eds), The Great Ordovician

Biodiversification Event. New York, Columbia University Press. 48-51.

STACEY, J.S. \& KRAMERS, J. D. 1975. Approximation of terrestrial lead isotope evolution by a two-stage model. Earth Planet Science Letters, 26, 207-201.

Stone, P., \& Rushton, A. W. A. 1983. Graptolites from the Ballantrae ophiolite complex and their structural implications. Scottish Journal of Geology, 19, 297-310.

Stone, P. \& Rushton, A. W. A. 2003. A Late Arenig (early Yapeenian) graptolite fauna and the coeval tectonic development of the Ballantrae Complex ophiolite, SW Scotland. Scottish Journal of Geology, 39, 29-40.

TANNER, P. G. W. \& Sutherland, S. 2007. Highland Border Complex, Scotland: a paradox resolved. Journal of the Geological Society, London, 164, 111-116.

TuCKER, R. D. \& MCKERROW, W. S. 1995. Early Palaeozoic chronology: a review in the light of new U-Pb zircon ages from Newfoundland and Britain. Canadian Journal of Earth Sciences, 32, 368-79.

VANDENBERG, A. H. M. \& COOPER, R. A. 1992. The Ordovician Graptolite Sequence of Australasia. Alcheringa, 16, 33-85.

Van StaAl, C. R., Dewey, J. F., MaC Niocaill, C. \& McKerrow, W. S. 1998. The Cambrian-Silurian tectonic evolution of the northern Appalachians and British Caledonides: history of a complex, west and southwest Pacific-type segment of Iapetus. In Blundell, D.J. and Scott, A. C. (eds) Lyell: The Past is the Key to the Present. Geological Society, London, Special Publications, 143, 199-242.

WiLliams, H. S. \& STEVENS, R. K. 1988. Early Ordovician (Arenig) graptolites of the Cow Head Group, western Newfoundland, Canada. Palaeontographica Canadiana, 51, 1167. 
Table 1. Correlation of the British standard Series and Stages with the Australasian stratigraphical scheme. The age of the graptolite fauna in the Tyrone Volcanic Group is highlighted, and selected U-Pb radiometric ages are indicated ( Tucker \& McKerrow 1995; ${ }^{2}$ this study; ${ }^{3}$ Landing et al. 1997)

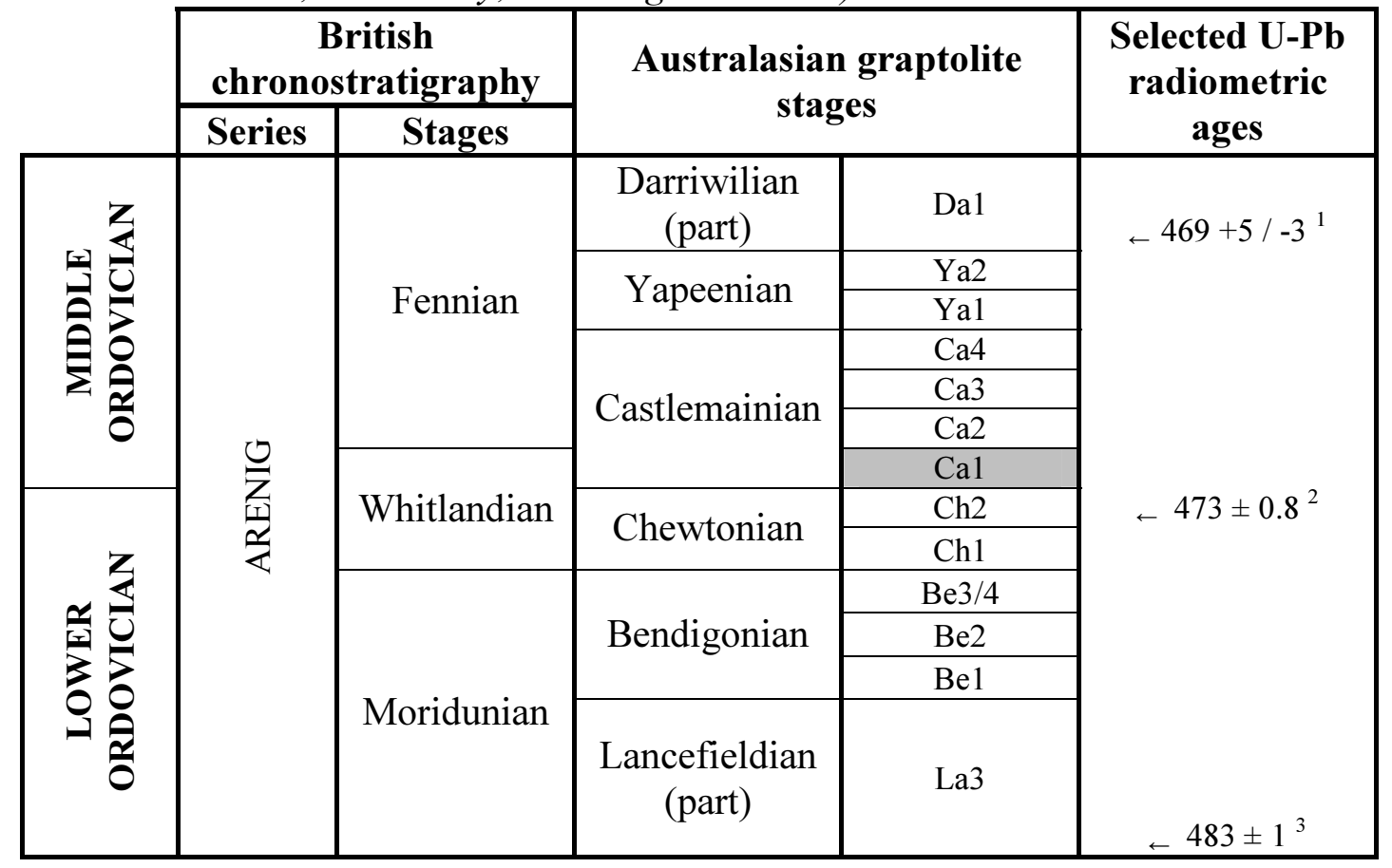




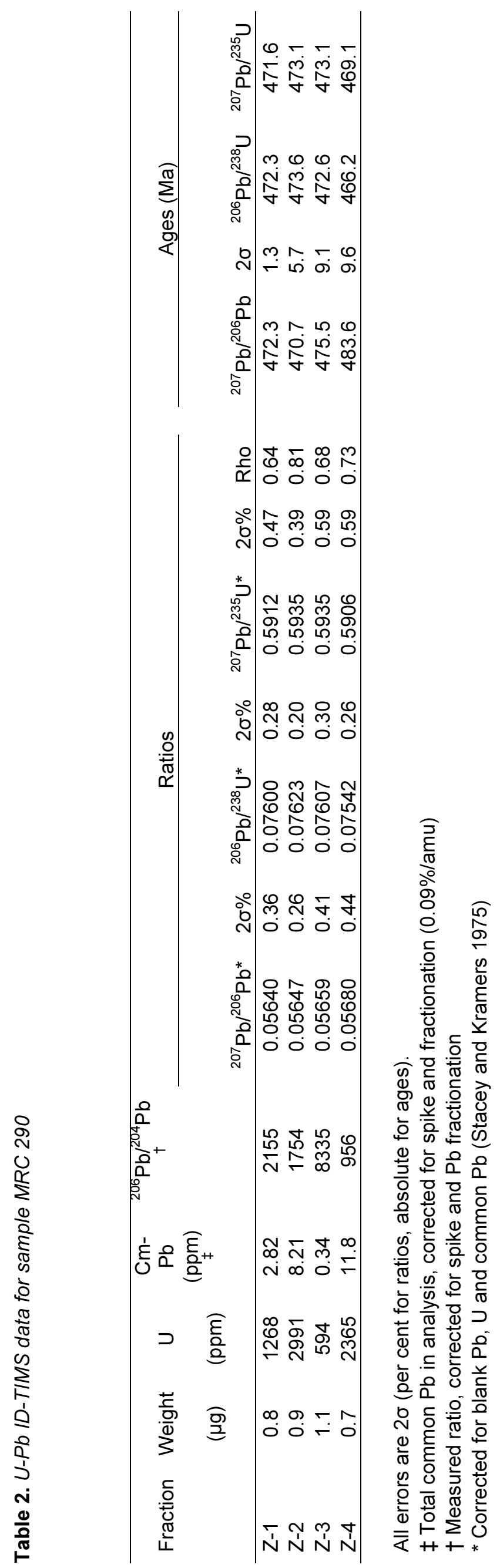




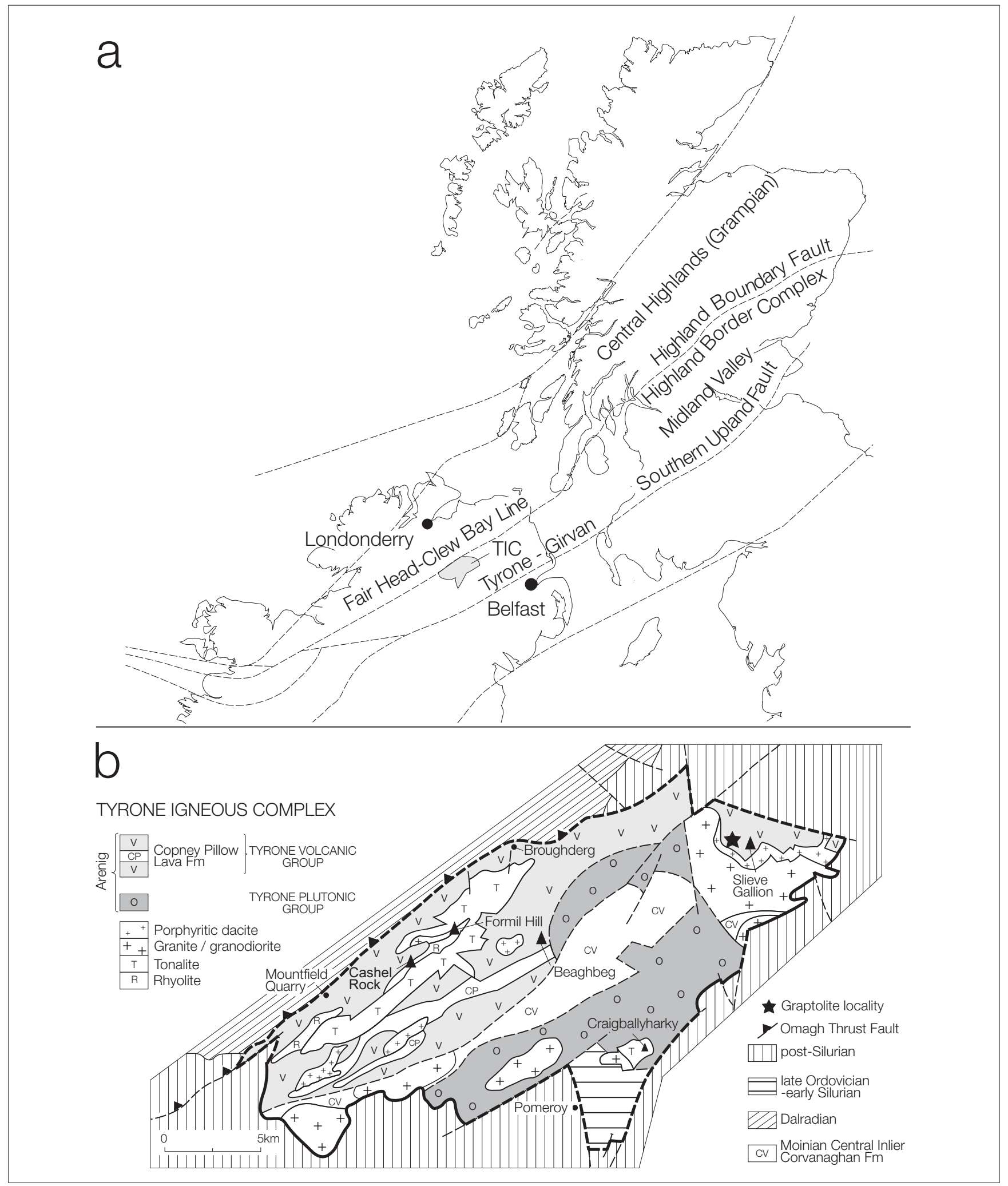

Fig. 1-(a) Location of the Tyrone Igneous Complex (TIC) in relation to basement terranes and bounding structures across the UK and Ireland. (b) Outline geological map of the Tyrone Igneous Complex and surrounding geology. 


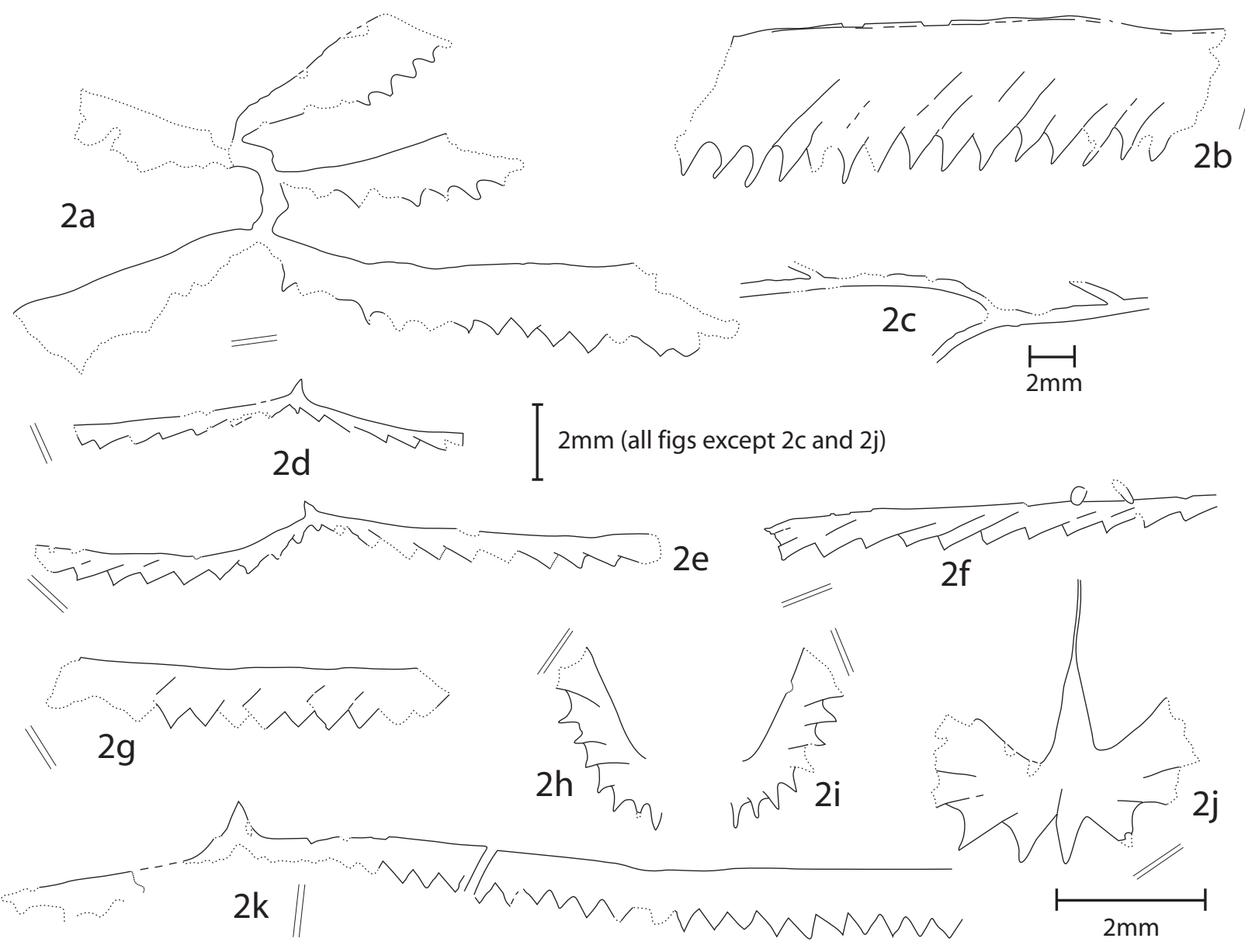

Fig. 2 Graptolites from Sruhanlealantawey, Slieve Gallion. Scale bars represent $2 \mathrm{~mm}$. The pairs of parallel lines represent the cleavage-trace in the plane of bedding. $(a, b$ ?) Dichograptus octobrachiatus (Hall): (a) proximal part of a robust pentad rhabdosome. Geological Museum, Trinity College Dublin, no. TCD.28759b, x5; (b) broad distal stipe fragment, possibly of the same species. Ulster Museum no. K29819, x5. (c) Dichograptid stipe with branches at intervals of $7 \mathrm{~mm}$ and $10 \mathrm{~mm}$. The specimen is too fragmented to be identified, but the branching pattern is similar to some Clonograptus species. Ulster Museum no. K29828, x3. (d-f, g, k) Didymograptellus nitidus (Hall), all x5: (d, e) slender proximal portions with dimensions similar to the lectotype of the species (Fortey \& Owens 1987, p. 264, fig. 118a). Both on Ulster Museum no. K29812; (f) near-proximal stipe fragment of a similar form, showing distal expansion, K29833; (g, k) broader forms with closer-set and more steeply inclined thecae, similar to specimens of $D$. nitidus figured by Williams \& Stevens (1988, text-fig. 35R, T, Y). K29815 and K29843. (j, h, i) Isograptus victoriae lunatus Harris: (j) juvenile proximal end with dimensions close to the mean for this subspecies (Cooper 1973, table, p. 112), and which appears to have only two pairs of pendent thecae. Ulster Museum no. K29835, x10; (h, i) near-proximal stipe fragment attributed to this species, K29811, and its counterpart, K29812, x5. 


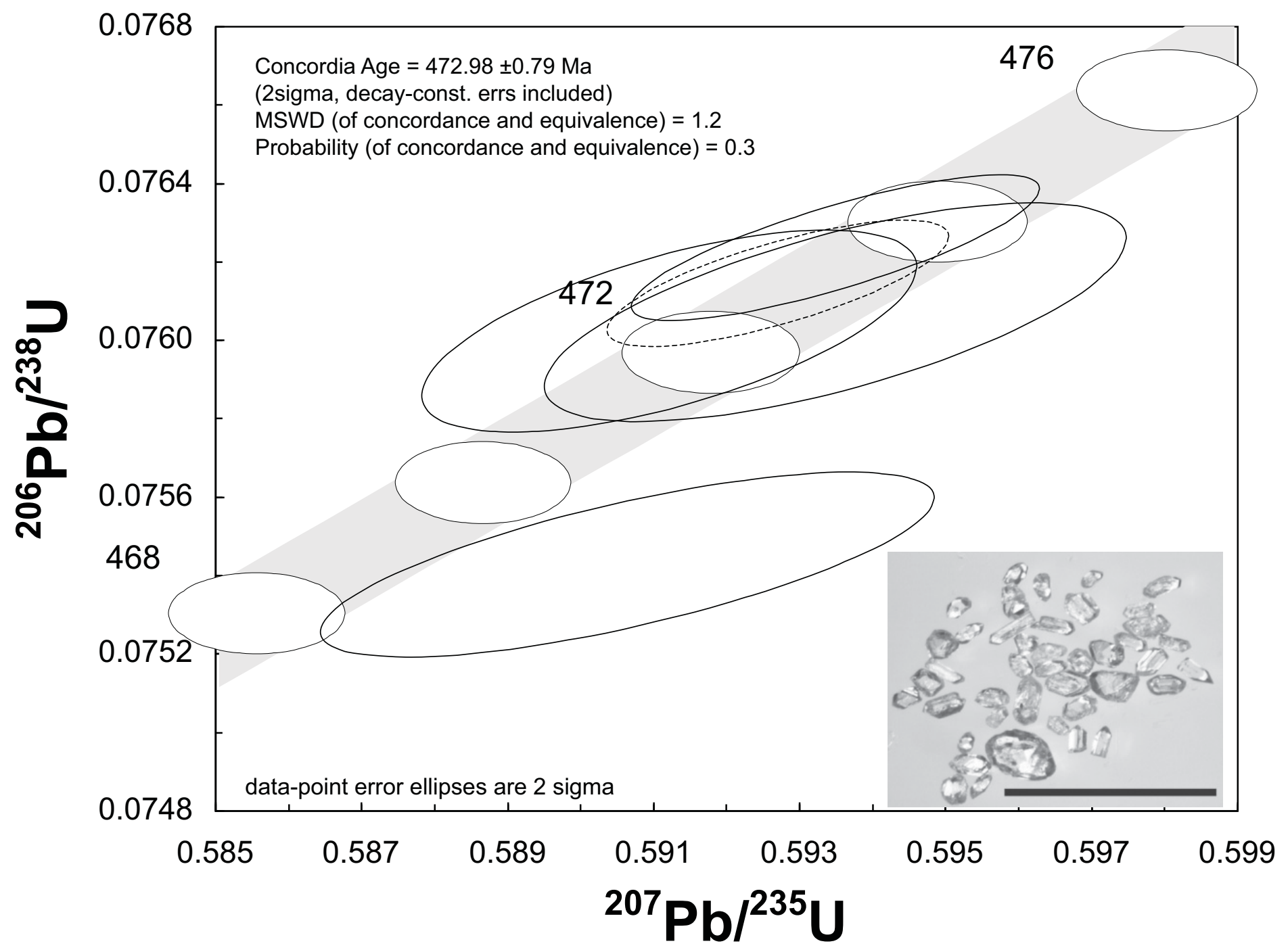

Fig. 3. U-Pb zircon concordia plot of from rhyolite sample MRC 290. Inset shows typical zircon morphology (scale bar $=500 \mu \mathrm{m}$ ). 